\title{
Hydroxychloroquine-Induced Creatine Kinase Elevation
}

\section{Hidroksiklorokin Kaynaklı Kreatin Kinaz Yükselmesi}

\author{
Sinem BAYRAKÇI'(ID), Nursel SÜRMELIOG̃LU²(ID), Ezgi ÖZYILMAZ3(ID)
}

${ }^{1}$ Intensive Care Unit, Faculty of Medicine, Cukurova University, Adana, Turkey

${ }^{2}$ Department of Clinical Pharmacy, Faculty of Pharmacy, Cukurova University, Adana, Turkey

${ }^{3}$ Department of Chest Diseases, Faculty of Medicine, Cukurova University, Adana, Turkey

Cite this article as: Bayrakçı S, Sürmelioğlu N, Özyılmaz E. Hydroxychloroquine-induced creatine kinase elevation. FLORA 2020;25(4):599-602.

\begin{abstract}
Long-term administration of hydroxychloroquine and chloroquine leads to deposition in the tissues including muscles, nerves and retina. Here, we report a case of hydroxychloroquine induced creatine kinase elevation after loading dose. An 80-year-old man with comorbidities, presented with a dry cough, high fever, diarrhea and general condition disorder ongoing for the last 3 days. The patient was admitted to the intensive care unit. The treatment was commenced with hydroxychloroquine. On the first day of treatment, the loading dose of hydroxychloroquine was started as $400 \mathrm{mg} \mathrm{q12h}$, and treatment was continued as $200 \mathrm{mg}$ q12h from the $3^{\text {rd }}$ dose. After the hydroxychloroquine loading dose, the patient's creatine kinase level increased, and after drug cessation, the level decreased. Hydroxychloroquine-induced creatine kinase elevated may be on not only long-term use but also acute period. Clinicians should have a high suspicion for hydroxychloroquine toxicity in patients with risk factors.
\end{abstract}

Key Words: Hydroxychloroquine; Toxicity; Creatine kinase; Adverse effect 
ÖZ

\title{
Hidroksiklorokin Kaynaklı Kreatin Kinaz Yükselmesi
}

\author{
Sinem BAYRAKÇI', Nursel SÜRMELIOG̃̃LU², Ezgi ÖZYILMAZ3
}

\footnotetext{
${ }^{1}$ Cukurova Üniversitesi Balcalı Hastanesi, Yog̃un Bakım Ünitesi, Adana, Türkiye

${ }^{2}$ Çukurova Üniversitesi Eczacılık Fakültesi, Klinik Eczacılık Anabilim Dalı, Adana, Türkiye

${ }^{3}$ Çukurova Üniversitesi Tıp Fakültesi, Göğüs Hastalıkıarı Anabilim Dalı, Adana, Türkiye
}

Hidroksiklorokin ve klorokin uzun süreli uygulamalarında, kas, sinir ve retina gibi dokularda birikebilmektedir. Bu raporda, hidroksiklorokinin yükleme dozu sonrası kreatin kinaz düzeyi yükselmesi gözlenen bir olgu sunulmaktadır. Komorbiditeleri bulunan 80 yaşında erkek hasta, son 3 gündür devam eden kuru öksürük, yüksek ateş, ishal ve genel durum bozukluğu şikayetleri ile hastaneye başvurmuş ve yoğun bakım ünitesine kabul edilmiştir. Tedavinin ilk gününde, hidroksiklorokin yükleme dozu 12 saatte bir 400 mg olarak başlanmış ve 3. dozdan itibaren 12 saatte bir 200 mg olarak devam edilmiştir. Hidroksiklorokinin yükleme dozundan sonra hastanın kreatin kinaz düzeyi artmış olup ilacın kesilmesinden sonra azalmıştır. Hidroksiklorokinin indüklediği kreatin kinaz düzeyi yükselmesi sadece uzun süreli kullanımda değil aynı zamanda akut dönemde de görülebilmektedir. Klinisyenler risk faktörleri olan hastalara hidroksiklorokin toksisitesi açısından şüphe ile yaklaşmalıdır.

Anahtar Kelimeler: Hidroksiklorokin; Toksisite; Kreatin kinaz; Yan etki

\section{INTRODUCTION}

Hydroxychloroquine (HCQ) and chloroquine (CQ) are antimalarial drugs that are also used in the treatment of various rheumatic diseases ${ }^{[1,2]}$. With the declaration on March $11^{\text {th }}, 2020$, by the World Health Organization that coronavirus disease 2019 (COVID-19) is a pandemic, CQ and HCQ have been sporadically used in treating Severe Acute Respiratory Syndrome Coronavirus 2 (SARS-CoV-2) infection due to their proposed immunomodulatory effect and also proposed usefulness in controlling the cytokine storm ${ }^{[3]}$.

HCQ is safer and better-tolerated than CQ, and the use of HCQ has been increased ${ }^{[4]}$. HCQs most common side effects include gastrointestinal symptoms, pruritus and dermatological changes that can occur in up to $10 \%$ of the patients. The most severe side effects have low incidence $^{[5,6]}$. HCQ is known to have significant lysosomal affinity. Long-term administration leads to deposition in tissues including the muscles, nerves and retina. They include neuromyopathy, cardiotoxicity and irreversible retinopathy ${ }^{[5,7]}$. Neuromyotoxicity is a rare side effect with a reported prevelance up to $6.7 \%$. It is characterized by proximal muscle weakness, generally normal creatine kinase (CK) levels, and characteristic ult- rastructural changes on muscle biopsy of curvilinear body formation ${ }^{[2,8,9]}$.

Here, we report a case of hydroxychloroquine induced CK elevation after loading dose.

\section{CASE}

An 80-year-old man with dementia, hypertension, and previous cerebrovascular accident presented with a dry cough, high fever, diarrhea and general condition disorder ongoing for the last 3 days to the emergency department. He was tachycardic, normotensive, Glasgow Coma Scale is 14 , oxygen saturation was $100 \%$ with a nasal cannula of 4-liter per minute oxygen support. The patient's PCR (polymerase chain reaction) test performed twice was negative, but since thorax computed tomography results were compatible with COVID-19, he was followed as a possible case. The patient was admitted to the COVID intensive care unit with hypernatremia, prerenal acute renal failure, and bilateral groundglass areas in the lung.

Treatment was commenced with HCQ, 0.45\% $\mathrm{NaCl}$, and 5\% Dextrose solution, Vitamin C, Vitamin B complex, Aspirin (100 mg q24h), Ranitidine (50 mg q24h). On the first day of treatment, the loading dose of HCQ was started 
as $400 \mathrm{mg} \mathrm{q} 12 \mathrm{~h}$, and treatment was continued as $200 \mathrm{mg} \mathrm{q} 12 \mathrm{~h}$ from the $3^{\text {rd }}$ dose. At the initial laboratory findings, serum CK of $126 \mathrm{U} / \mathrm{L}$ (normal range, 26-140 U/L), creatinine kinase MB (CK-MB) of $5 \mathrm{ng} / \mathrm{mL}$ (normal range, 0.0-4.5 $\mathrm{ng} / \mathrm{mL}$ ) and creatinine $(\mathrm{Cr})$ of 0.9 (normal range, $0.5-0.8 \mathrm{mg} / \mathrm{dL})$. After the $2^{\text {nd }}$ and $4^{\text {th }}$ dose of HCQ, CK was increased to 233 U/L, CK-MB: 5 $\mathrm{ng} / \mathrm{mL}$; and CK: $3715 \mathrm{U} / \mathrm{L}, \mathrm{CK}-\mathrm{MB}: 37 \mathrm{ng} / \mathrm{mL}$, respectively. HCQ treatment was stopped after the $6^{\text {th }}$ dose. CK levels decreased 72 hours after cessation (Table 1). During the treatment, liver functions were normal and kidney functions returned to normal. Drug-related adverse drug reaction (ADR) was evaluated through the Naranjo scale
10, and the score was calculated as 3 (Table 2).

HCQ is cationic, amphiphilic compounds with long half-lives of 3.5-12 days. It has a significant lysosomal affinity ${ }^{[1]}$. HCQ induced myopathy is thought to be due to the accumulation of hydroxychloroquine in lysosomes ${ }^{[2]}$. In myopathy induced by HCQ, although muscle enzymes are generally stated to be normal ${ }^{[2]}, \mathrm{CK}$ and CK-MB increased rapidly in this case.

Risk factors for myotoxicity are poorly understood but may include the Caucasian race, renal failure, older age, female sex and concomitant use of other myotoxic drugs ${ }^{[1,4]}$. In this case, patient had renal dysfunction and older age.

Table 1. Some laboratory findings in the process of hydroxychloroquine treatment

\begin{tabular}{lccc} 
Days & $\mathrm{Cr}(\mathrm{mg} / \mathrm{dL})$ & $\mathrm{CK}(\mathrm{U} / \mathrm{L})$ & $\mathrm{CK}-\mathrm{MB}(\mathbf{n g} / \mathbf{m L})$ \\
\hline 1. & 3.8 & 126 & 1.9 \\
2. & 3.23 & 233 & 5 \\
3. & 2.04 & 3715 & 37 \\
7. & 1.34 & 1750 & 23.2 \\
13. & 0.72 & 166 & \\
\hline
\end{tabular}

${ }^{*}$ Cr: Creatinin, CK: Creatine Kinase, CK-MB: Creatine kinase-MB.

Table 2. Adverse drug reaction scale ${ }^{[10]}$

1. Are there previous conclusive reports on this reaction?

$\begin{array}{cccc}\text { Yes } & \text { No } & \text { Do not know } & \text { Score } \\ +1 & 0 & 0 & +1 \\ +2 & -1 & 0 & +2 \\ +1 & 0 & 0 & +1 \\ +2 & -1 & 0 & 0 \\ -1 & +2 & 0 & -1 \\ -1 & +1 & 0 & 0 \\ +1 & 0 & 0 & 0 \\ +1 & 0 & 0 & 0 \\ +1 & 0 & 0 & 0 \\ +1 & 0 & 0 & 0 \\ & \text { Total Score } & & 3\end{array}$

2. Did the adverse event appear after the suspected drug was administered?

3. Did the adverse reaction improve when the drug was discontinued or a spesific antagonist was administered?

4. Did the adverse reaction reappear when the drug administered?

5. Are there alternative causes (other than the drug) that could on their own have caused the reaction?

6. Did the reaction reappear when a placebo was given?

7. Was the drug detected in the blood (or other fluids) in concentrations known to be toxic?

8. Was the reaction more severe when the dose was increased, or less severe when the dose was decreased?

9. Did the patient have a similar reaction to the same or similar drugs in any previous exposure?

10. Was the adverse event confirmed by any objective evidence?

*The adverse drug reaction was assigned to a probability category from the total score as follows: definite $\geq 9$, probable 5 to 8 , possible 1 to 4 , doubtful $\leq 0$. 
Another risk factor is reported to be the duration of treatment. In the literature, myopathy and/ or muscle enzyme elevation has generally been reported after long-term HCQ treatment $[1,2,4]$. But in this case, $\mathrm{CK}$ and $\mathrm{CK}-\mathrm{MB}$ increased after the loading dose. Interestingly, although the duration of treatment may lead to progressive and additive changes, it is not clear if the occurrence of HCQ-induced myotoxicity is dose-dependent ${ }^{[4]}$.

Naranjo algorithm was used for objective evaluation of $\mathrm{CK}$ elevation due to $\mathrm{HCQ}$. According to this algorithm, its total score was 3 points. This score shows that the side effect was possibly (1-4) caused by drugs (Table 2). In addition, there are no other drugs known to be myotoxic in the treatment, but it is reported that COVID-19 can cause CK elevation ${ }^{[11]}$.

HCQ-induced muscle enzyme elevation may be on not only long-term use but also acute period. If it is not noticed early, it can have serious consequences. Clinicians should have a high suspicion for HCQ toxicity in patients with risk factors.

\section{CONFLICT of INTEREST}

The authors have disclosed that they do not have any potential conflicts of interest.

\section{AUTHORSHIP CONTRIBUTIONS}

Concept/Design: All of authors

Analysis/Interpretation: SB, NS

Data Acquisition: All of authors

Writting: SB, NS

Final Approval: All of authors

\section{REFERENCES}

1. Abdel-Hamid H, Oddis CV, Lacomis D. Severe hydroxychloroquine myopathy. Muscle Nerve 2008;38(3):1206-10.

2. Takizawa N, Fujita Y. A rare but reversible cause of myopathy: hydroxychloroquine induced myopathy. Am J Med 1987;82(3):447.

3. Yıldırım F. Chloroquine and hydroxychloroquine in treatment of COVID-19 disease. I Crit Intensive Care 2020;11(Suppl.1):23-26.

4. Kwon JB, Kleiner A, Ishida K, Godown J, Ciafaloni E, Looney R. Hydroxychloroquine-induced myopathy. JCR-J Clin Rheumatol 2010;16(1):28-31

5. Sinha N, Balayla G. Hydroxychloroquine and COVID-19. Postgrad Med J 2020;0:1-6.

6. Abdulaziz N, Shah AR, McCune WJ. Hydroxychloroquine: balancing the need to maintain therapeutic levels with ocular safety: an update. Curr Opin Rheumatol 2018;30:249-55.

7. Taylor WRJ, White NJ. Antimalarial drug toxicity: a review. Drug Saf 2004;27:25-61.

8. Khosa S, Khanlou N, Khosa GS, Mishra SK. Hydroxychloroquine-induced autophagic vacuolar myopathy with mitochondrial abnormalities. Neuropathology 2018;38(6):646-52.

9. Siddiqui AK, Huberfeld SI, Weidenheim KM, Einberg KR, Efferen LS. Hydroxychloroquine-induced toxic myopathy causing respiratory failure. Chest 2007;131(2):588-90.

10. Naranjo CA, Busto U, Sellers EM, Sandor P, Ruiz I, Roberts $E A$, et al. A method for estimating the probability of adverse drug reactions. Clin Pharmacol Ther 1981;30(2):239-45.

11. Chan KH, Farouji I, Harnoud AA, Slim J. Weakness and elevated creatinine kinase as the initial presentation of coronavirus disease 2019 (COVID-19). Am J Emerg Med 2020;38(7):1548.e1-1548.e3.

\section{Address for Correspondence/Yazıșma Adresi}

Asistan Dr. Nursel SÜRMELIOĞLU

Cukurova Üniversitesi Eczac1lk Fakültesi

Klinik Eczacılık Anabilim Dalı

Adana-Türkıye

E-mail: nurselisci@gmail.com 